\title{
OCCURRENCE OF WEED SPECIES IN Jatropha curcas INTERCROPPING SYSTEMS $^{1}$
}

\author{
Ocorrência de Plantas Daninhas em Sistemas Consorciados de Pinhão Manso
}

CONCENÇO, G. ${ }^{2}$, SILVA, C.J. ${ }^{2}$, CORREIA, I.V.T. ${ }^{2}$, SILVA, J.A.N. ${ }^{2}$, SANTOS, S.A. ${ }^{2}$, FRÓES, A.L. ${ }^{2}$,
FÁBRIS, D.N. ${ }^{2}$, and STAUT, L.A. ${ }^{2}$

\begin{abstract}
This study aimed to evaluate the level of infestation by weed species in a consolidated Jatropha plantation, as a function of the plant species grown in interrows. The experiment was installed in 2006 at the district of Itahum, city of Dourados, state of Mato Grosso do Sul, Brazil, made possible through a partnership between Embrapa Western Agriculture and Paraiso Farm. Treatments consisted of (1) Jatropha in monocrop, with no plant at the interrrows; or the following plants cultivaded at the interrows of Jatropha: (2) Stylosanthes spp.; (3) Brachiaria ruziziensis; (4) Brachiaria ruziziensis + Stylosanthess pp.; (5) Brachiaria humidicola; (6) Panicum maximum cv. massai; (7) Cajanus cajan cv. anão; (8) Crotalaria spectabilis; (9) Crop rotation system 1 - (maize second crop - Crambe abyssinica - soybean peanut); and (10) Crop rotation system 2 - (cowpea - radish - maize - cowpea) conducted for two years. Phytosociological characterization of weed species was accomplished in 2011 based on the Ecological Approach. Estimations of relative abundance, frequency, dominance and Importance Value Index were obtained. Areas were also characterized by the diversity coefficients of Simpson and modified Shannon-Weiner, and then grouped by cluster analysis. Areas with low soil coverage resulted in higher infestation levels; crop rotation in the interrows of Jatropha produced a significant reduction in weed infestation, but the lowest infestation levels were observed when grasses were grown intercropped with Jatropha. Lower diversity coefficients were associated with occurrence of the most troublesome weed species. In the first years after planting Jatropha, species of Brachiaria or a crop rotation involving species with high mulching ability and whose biomass exhibit a high C:N ratio, should be established in the interrows to avoid problems with weeds infestation.
\end{abstract}

Keywords: Jatropha crop, infestation, phytosociology.

RESUMO: Objetivou-se com este estudo avaliar o nivel de infestação por plantas daninhas em uma plantação consolidada de pinhão-manso em função da espécie cultivada nas entrelinhas da cultura. O experimento foi instalado em 2006 no distrito de Itahum, cidade de Dourados, Estado de Mato Grosso do Sul, tendo sido viabilizado por uma parceria entre a Fazenda Paraíso e a Embrapa Agropecuária Oeste. Os tratamentos consistiram do cultivo solteiro (1) ou das seguintes espécies cultivadas nas entrelinhas da cultura: (2) Stylosanthes spp.; (3) Brachiaria ruziziensis; (4) Brachiaria ruziziensis + Stylosanthes spp.; (5) Brachiaria humidicola; (6) Panicum maximum cv. massai; (7) Cajanus cajan cv. anão; (8) Crotalaria spectabilis; (9) sistema de rotação 1 - (milho safrinha-Crambe abyssinica - soja-amendoim); e (10) sistema de rotação 2 (feijão-caupi - nabo forrageiro - milho - feijão-caupi) conduzidos por dois anos. A caracterização fitossociológica foi realizada em 2011, seguindo a perspectiva ecológica, sendo obtidos a abundância, a frequência, a dominância e o indice de valor de importância. As áreas foram ainda intracaracterizadas pelos coeficientes de diversidade de Simpson e de Shannon-Weiner modificado e, posteriormente, intercaracterizadas por análise de agrupamento. Áreas com cobertura do solo deficiente resultaram nos maiores índices de infestação; a rotação de culturas nas entrelinhas do pinhão-manso propiciou redução na infestação por plantas daninhas, porém a menor infestação foi constatada quando gramineas foram cultivadas nas entrelinhas da cultura. Menores coeficientes de diversidade foram associados

Recebido para publicação em 2.9.2013 e aprovado em 24.12.2013.

Embrapa Western Agriculture, Dourados-MS, Brazil, <germani.concenco@embrapa.br>.

Planta Daninha, Viçosa-MG, v. 32, n. 2, p. 327-334, 2014 
à ocorrência das plantas daninhas de mais dificil controle. Nos primeiros anos do plantio de pinhãomanso, espécies de Brachiaria ou rotações de cultivos envolvendo espécies com grande produção de biomassa com alta relação C:N devem ser estabelecidas nas entrelinhas, a fim de evitar problemas com infestações por plantas daninhas.

Palavras-chave: pinhão-manso, infestação, fitossociologia.

\section{INTRODUCTION}

The partial or total substitution of biofuels for petroleum-based fuel oil has become a topic of strategic security for many countries, aiming to meet both the increasing demand for energy and the new required limits for emission of gaseous pollutants (Rocha et al., 2010).

Among the factors which limit Jatropha's yield, the region of cultivation, the cropping techniques, plant age, rain amount and distribution, soil fertility and management system are the most important (Oliveira \& Silva, 2011). Studies related to weed behavior are essential for agriculture sustainability in tropical soils, since their interference can cause significant yield losses, especially in crops with lower competitive ability. Weed control practices assume a strategic position in Jatropha plantations, since this crop is highly sensitive to competition with weed species (Staut et al., 2011).

Jatropha is usually grown in monoculture, and its interrows usually remain clear, with no economical crops during the growing season (Aun, 2008). Several studies indicate that, if the soil is kept clear of plant coverage, weed infestation tends to be higher due to the available space for establishment and better access of seedlings to light (Silva et al., 2007). Under this scenario, these weeds will produce more seeds and the problem of weed infestation tends to increase exponentially in subsequent years.

Even considering the changes both in the number of weed individuals present and in the number of species (as a consequence of mulching and shading by forages or crops in the interrows of Jatropha), some weed species may vary in their response to a given management practice (Voll et al., 2005). Understanding both the level of occurrence and the composition of the weed community inside each management or cropping system is important for planning an efficient set of practices to control these species. By using the innate ability of plants to inhibit the growth of other species, it is possible to maximize yields and reduce expenses for weed control (Velykis \& Satkus, 2006).

Phytosociological studies allow one to assess species composition and systematically estimate the abundance, frequency and dominance of each plant species present. With these data it is possible to rank species in terms of importance of infestation in each cropping system (Gomes et al., 2010), focusing management practices on the most important weed species. Coefficients of diversity also support inferences about the level of imbalance of a plant community, assisting in the determination of the main weed species responsible for the infestation. Areas under specific management systems can also be compared in terms of similarity of infestation.This allows one to group distinct management systems for effectiveness in managing given weed species (Barbour et al., 1998).

This study aimed to evaluate the level of infestation by weed species in a consolidated Jatropha plantation, as a function of the plant species grown in interrows.

\section{MATERIAL AND METHODS}

The experiment was installed in the district of Itahum, city of Dourados, state of Mato Grosso do Sul, Brazil, at the coordinates $22^{\circ} 05^{\prime} 44^{\prime \prime} \mathrm{S}$ and $55^{\circ} 18^{\prime} 48^{\prime \prime} \mathrm{W}$, enabled by a partnership between Embrapa Western Agriculture and Paraiso Farm. The soil is classified as Typic Haplortox, with average clay content of $200 \mathrm{~g} \mathrm{~kg}^{-1}$. Long-term monthly rain averages, as well as actual rainfall recorded 
during the duration of the trial are presented in Figure 1.

The Jatropha plantation was installed in November 2006, at Paraiso Farm using a notill system, by depositing three seeds per hill. After emergence, only the most vigorous seedling was left in each hill. Planting rows were spaced at $3 \mathrm{~m}$ and plants were spaced at $2 \mathrm{~m}$ within the row. In the 2006/07 and 2007/ 08 growing seasons the usual management practices were applied to the field. No treatments were evaluated at this period, since this study aimed to establish intercopping with adult Jatropha plants. The experiment was initiated in 2008, with Jatropha plants well developed and established.

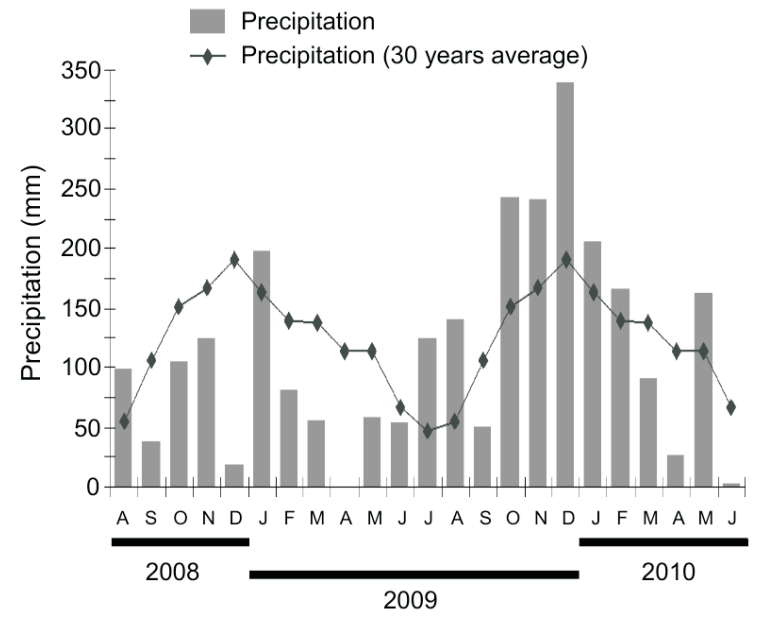

Figure 1 - Monthly precipitation in the 2008/2009 and 2009/ 2010 growing seasons in comparison to the historical precipitation averages. Source: Weather Station at Embrapa Western Agriculture Center, Dourados-MS, Brazil.
Experimental plots were comprised of four rows of plants with six plants per row (144 $\mathrm{m}^{2}$ per plot). Treatments are listed in Table 1. Fertilization was accomplished in the planting row by applying on the soil surface, at the third and fourth growing seasons, $400 \mathrm{~kg} \mathrm{ha}^{-1}$ per year of NPK 08-20-20 split into two treatments - half in October (2008 and 2009) and half in March (2009 and 2010). Treatments with crop rotation (Areas 9 and 10) were managed and fertilized according to the official recommendations for each crop. The remainder of the treatments did not receive any fertilizer.

The intercropped species were managed by mowing according to management height indicated by the research for each species. The resulting stubble was uniformly distributed on soil within the plot for mulching (Silva et al., 2012).

Weed management in the control plots and at the borders of the experiment was done by applying the herbicide glyphosate at a rate of $1.8 \mathrm{~kg} \mathrm{ha}^{-1}$ of acid equivalent three times per year. In the interrow areas, weed plants were eliminated by hoeing when necessary. Pest management was accomplished using an integrated approach (IPM), considering the system (Jatropha and grain crops). We monitored plots constantly, looking for the threshold level in order to avoid unnecessary insecticide applications. For the forage species no pest management was needed.

Phytosociological characterization of weed species emerged from the soil seed bank

Table 1 - Intercropping systems under study, involving Jatropha curcas plantations. Embrapa Western Agriculture, Dourados-MS, Brazil, 2012

\begin{tabular}{|c|c|}
\hline Area & Management system \\
\hline Area 1 & Jatropha in monocrop- no species grown in inter-rows. Weeds controlled with the herbicide glyphosate. \\
\hline Area 2 & Stylosanthes spp. (S. capitata + S. macrocephala), $5 \mathrm{~kg} \mathrm{ha}^{-1}$ of pure and viable seeds \\
\hline Area 3 & Brachiaria ruziziensis cv. Ruziziensis, $5 \mathrm{~kg} \mathrm{ha}^{-1}$ of pure and viable seeds \\
\hline Area 4 & $\begin{array}{l}\text { Brachiaria ruziziensis cv. Ruziziensis, } 5 \mathrm{~kg} \mathrm{ha}^{-1} \text { of pure and viable seeds }+ \text { Stylosanthes spp., } 5 \mathrm{~kg} \mathrm{ha}^{-1} \text { of pure } \\
\text { and viable seeds }\end{array}$ \\
\hline Area 5 & Brachiaria humidicola cv. Humidicola, $10 \mathrm{~kg} \mathrm{ha}^{-1}$ of pure and viable seeds \\
\hline Area 6 & Panicum maximum cv. Massai, $8 \mathrm{~kg} \mathrm{ha}^{-1}$ of pure and viable seeds \\
\hline Area 7 & Cajanus cajan cv. Anão, $15 \mathrm{~kg} \mathrm{ha}^{-1}$ of pure and viable seeds \\
\hline Area 8 & Crotalaria spectabilis, $15 \mathrm{~kg} \mathrm{ha}^{-1}$ of pure and viable seeds \\
\hline Area 9 & Crop rotation system $1-$ (maize second crop - Crambe abyssinica - soybean - peanut \\
\hline Area 10 & Crop rotation system 2 - (cowpea - radish - maize - cowpea) \\
\hline
\end{tabular}

All management systems described were installed in the inter-rows of Jatropha curcas plantations for two consecutive years. 
(plants not efficiently controlled by the last chemical or mechanical weed management were not considered) was carried out for all areas in March 2011 (the time of year with the greatest infestation). For that, the Random Quadrats method (Barbour et al., 1998) was used and two subsamples of $0.50 \times 0.50 \mathrm{~m}$ were evaluated in each plot. In this study, due to the use of an ecological approach, the group formed by the four replications of the same treatment was called "area", because it represents a given management system. Thus, the result for each area was based on eight sampled points (two subsamples per replication $\mathrm{x}$ four replications per treatment). All the emerged seedlings inside the square were identified by species, collected and stored in paper bags for each sampled area. They were dried in an oven with continuous air circulation for dry mass determination. When applicable, results were calculated per square meter of plot area.

We estimated relative abundance (based on number of individuals), relative frequency (based on the distribution of the species in the area) and relative dominance (based on the ability of each species to accumulate dry mass) for each species present. The Importance Value Index (I.V.I.), which ranks species in terms of importance within the studied area, was also determined (Barbour et al., 1998). Areas were also characterized by the diversity coefficients of Simpson (D) and modified Shannon-Weiner (H') (Barbour et al., 1998). After these analyses, we compared areas by Jaccard's binary asymmetric similarity coefficient (Barbour et al., 1998) to estimate the current degree of weed similarity between areas after two years of treatment.

Based on Jaccard's coefficient, we used cluster analysis to group areas, considering the qualitative trait only (presence or absence of the species), according to the dissimilarities obtained from the inverse of Jaccard's similarity matrix. We obtained hierarchical grouping from the distance matrix (dissimilarities) (Barbour et al., 1998) by using the Unweighted Pair Group Method with Arithmethic Mean (UPGMA) method (Sneath \& Sokal, 1973). We accomplished grouping validation by the cophenetic correlation coefficient, obtained by the Pearson linear correlation between the cophenetic matrix and the original matrix of distances (Sokal \& Rohlf, 1962). Threshold level for defining the number of groups was considered as the simple mean of the original matrix of Jaccard.

All analyses were run under the $R$ Statistical Environment (R-development Core Team, 2012), by using functions made available by the following additional packages: graphics, vegan, Hmisc, cluster and ExpDes. All formulas and procedures, both in sampling and description of the areas, as well as in species clustering, followed the requirements pointed out by Barbour et al. (1998) for synecological analyses.

\section{RESULTS AND DISCUSSION}

The rainfall distribution differed between years in comparison to the historic averages (Figure 1). In the 2008/09 cropping season precipitation was considerably less than the long-term average, while in 2009/10 rains were more than expected. So, although new plants may have suffered during the first summer, they had adequate rain in the following cropping season, and both Jatropha and the intercropped species developed as expected.

In the third year, when the evaluations of weed species began, we observed that all areas with presence of grass species, especially $B$. ruziziensis (Areas 3 and 4), but also B. humidicola (area 5) and P. maximum (area 6), exhibited relatively low levels of weed infestation (Figure 2). Areas with crop rotations (9 and 10) exhibited intermediate levels of infestation while areas intercropped with broadleaves - Stylosanthes sp. (area 2), C. cajan (area 7) and C. spectabilis (area 8) exhibited relatively high levels of infestation compared to areas either with grasses or under crop rotation. This was measured mainly in terms of dry mass accumulated by the weed species (Figure 2). Jatropha in monocrop (area 1) did not exhibit levels of infestation significantly higher than the other treatments. This is attributed to the frequent glyphosate applications in the previous two years (from the initiation of the trial) exclusively in this treatment, which prevented production of new 


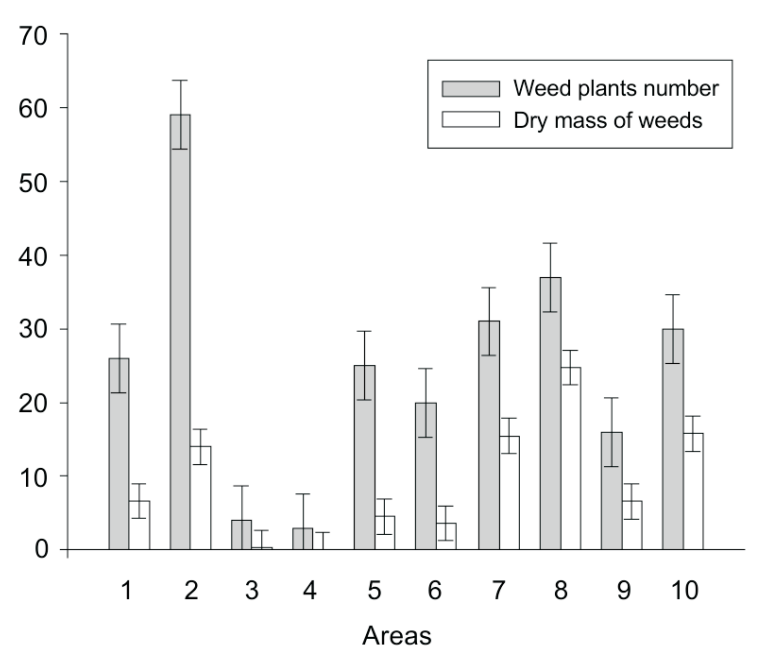

Figure 2 - Number of plants of weed species per square meter and dry mass of weeds $\left(\mathrm{g} \mathrm{m}^{2}\right)$ in the distinct intercropping systems involving Jatropha curcas plantations. Embrapa Western Agriculture, Dourados-MS, Brazil, 2012.

seeds and caused a systematic reduction in infestation.

In comparative terms, areas with B. ruziziensis exhibited infestation (in terms of dry mass of weeds) less than $5 \%$ of the observed for the areas with $C$. spectabilis and C. cajan (Figure 2). Furthermore, areas under crop rotation exhibited infestation equivalent to $55 \%$ of that observed in the areas with C. spectabilis and C. cajan. The areas with frequent application of herbicides for weed management (Jatropha in monocrop, area 1) exhibited levels of infestation (in terms of dry mass of weeds) equivalent to those correctly managed with forage species or crop rotation, with only the areas with C. spectabilis or C. cajan having higher infestation rates than the monocrop (Figure 2).

The phytosociological survey showed significant distinctions among treatments in terms of the most important weed species (Table 2). Overall, the predominant weed species was Synedrellopsis grisebacchii, present in nine of the ten evaluated areas, and ranked as the most important in eight of them. S. grisebachii, commonly called Straggler Daisy, is native to South America, often found in the Southern and West Central regions of Brazil (Carvalho et al., 2011). The same authors highlight its intense branching and dominance, presence of stolons and distribution in a wide range of soils.

The area with no crop planted together with Jatropha (control plot), with chemical weed control (area 1) exhibited three weed species, Richardia brasiliensis and S. grisebachii, which

Table 2 - Phytosociological analysis of weeds occurrence in distinct intercropping systems involving Jatropha curcas plantations. Embrapa Western Agriculture, Dourados-MS, Brazil, 2012

\begin{tabular}{|c|c|c|c|c|}
\hline & $\mathrm{AB}^{\frac{1 /}{}}$ & $\mathrm{FR}^{1 / \prime}$ & $\mathrm{DO}^{1 / \prime}$ & $\mathrm{IVI}^{1 /}$ \\
\hline & \multicolumn{4}{|c|}{ Area $1^{2 / 1}$} \\
\hline G. coarctatum & 3.9 & 20.0 & 1.2 & 8.4 \\
\hline S. grisebachii & 92.3 & 60.0 & 94.1 & 82.1 \\
\hline \multirow[t]{2}{*}{ R. brasiliensis } & 3.8 & 20.0 & 4.7 & 9.5 \\
\hline & \multicolumn{4}{|c|}{ Area $2^{2 /}$} \\
\hline C. bonariensis & 1.7 & 7.7 & 1.3 & 3.6 \\
\hline G. coarctatum & 0.6 & 7.7 & 0.1 & 2.8 \\
\hline S. grisebachii & 92.1 & 60.5 & 98.4 & 83.7 \\
\hline R. brasiliensis & 2.3 & 23.1 & 0.2 & 8.5 \\
\hline \multirow[t]{2}{*}{ C. benghalensis } & 3.4 & 1.0 & 0.1 & 1.5 \\
\hline & \multicolumn{4}{|c|}{ Area $3^{2 /}$} \\
\hline \multirow[t]{2}{*}{ S. grisebachii } & 100 & 100 & 100 & 100 \\
\hline & \multicolumn{4}{|c|}{ Area $4^{2 /}$} \\
\hline \multirow[t]{2}{*}{ R. brasiliensis } & 100 & 100 & 100 & 100 \\
\hline & \multicolumn{4}{|c|}{ Area $5^{\frac{2}{2}}$} \\
\hline S. grisebachii & 84.0 & 57.0 & 98.7 & 79.8 \\
\hline R. brasiliensis & 12.0 & 42.9 & 1.3 & 18.7 \\
\hline \multirow[t]{2}{*}{ T. paniculatum } & 4.0 & 0.1 & 0.0 & 1.5 \\
\hline & \multicolumn{4}{|c|}{ Area $6^{2 / 1}$} \\
\hline \multirow[t]{2}{*}{ S. grisebachii } & 100 & 100 & 100 & 100 \\
\hline & \multicolumn{4}{|c|}{ Area $7^{2 /}$} \\
\hline C. bonariensis & 6.4 & 10.0 & 54.7 & 23.7 \\
\hline S. grisebachii & 77.4 & 50.0 & 36.7 & 54.7 \\
\hline \multirow[t]{2}{*}{ R. brasiliensis } & 16.1 & 40.0 & 8.6 & 21.6 \\
\hline & \multicolumn{4}{|c|}{ Area $8^{2 /}$} \\
\hline S. arvensis & 5.4 & 16.7 & 19.4 & 13.8 \\
\hline S. grisebachii & 86.5 & 50.0 & 80.3 & 72.3 \\
\hline \multirow[t]{2}{*}{ R. brasiliensis } & 8.1 & 33.3 & 0.4 & 13.9 \\
\hline & \multicolumn{4}{|c|}{ Area $9^{2 /}$} \\
\hline S. grisebachii & 12.5 & 25.0 & 8.1 & 15.2 \\
\hline R. sativus & 6.3 & 12.5 & 0.1 & 6.3 \\
\hline R. brasiliensis & 62.5 & 50.0 & 50.8 & 54.4 \\
\hline \multirow[t]{2}{*}{ C. benghalensis } & 18.8 & 12.5 & 41.1 & 24.1 \\
\hline & \multicolumn{4}{|c|}{ Area $10^{2 /}$} \\
\hline C. bonariensis & 6.7 & 18.2 & 9.9 & 11.6 \\
\hline S. grisebachii & 50.0 & 18.2 & 85.5 & 51.2 \\
\hline R. sativus & 10.0 & 18.2 & 0.1 & 9.4 \\
\hline R. brasiliensis & 33.3 & 45.4 & 4.5 & 27.8 \\
\hline
\end{tabular}

$1 / \mathrm{AB}=$ abundance $; \mathrm{FR}=$ frequence $; \mathrm{DO}=$ dominance; $\mathrm{IVI}=$ importance value for each plant species. All parameters are presented in relative terms (\%). . $^{-}$Please see treatment descriptions in Table 1. 
are highly tolerant to the herbicide glyphosate (Table 2). In this area, S. grisebachii was solely responsible for $82 \%$ of the infestation (Table 2). When a plant community is submitted to a given selection factor, e.g. a specific herbicide, those species naturally most tolerant (or even resistant) to that herbicide will survive (Vargas \& Roman, 2004). These plants produce seeds and increase the soil seed bank, increasing its occurrence.

The area with estilosantes grown in the interrows was the most infested (Figure 2), exhibiting a larger number of weed species in most of the treatments (Table 2). Estilosantes presents a slow initial growth, mainly in the winter (Brolmann, 1979); this was aggravated by occurrence of frosts in 2008 and 2009 winters, which damaged shoots and reduced its resprouting ability. In this trial there was the additional effect of the shading caused by Jatropha, which probably reduced its growth performance. S. grisebachii was the most important weed species in this area, representing $83.7 \%$ of the total infestation (Table 2). The other weed species observed did not represent more than $10 \%$ of the infestation in each area.

Larger infestations were also observed in areas 7 and 8 - Jatropha intercropped with either Cajanus cajan or Crotalaria spectabilis, respectively, where $S$. grisebachii was the most important weed species, followed by $R$. brasiliensis in both areas and $C$. bonariensis in the intercrop with $C$. cajan (Table 2). When these areas are compared to those where grass species are present in the intercrop (areas 3, 4, 5, and 6), the same weed species are common in all areas. S. grisebachii was the only species reported in areas 3 and 6; $R$. brasiliensis was the only one present in area 4 , and area 5 exhibited both species plus Talinum paniculatum (Table 2).

The level of infestation in a given area depends on several factors; among them, the richness of the soil seed bank is the most important. Concenço et al. (2011a) studied some long-term experiments, suggesting in the results that at least five years of distinct management should be applied to a given area in order to significantly change the soil seed bank. This may mean that the time of specific management techniques used in these treatments (two years) is not long enough to change plant composition present in the soil seed bank.

Crop rotation systems (areas 9 and 10) also differed in terms of level of infestation (Figure 2) and partially in terms of weed species present (Table 2). In general, the crop rotation involving cowpea (area 10) exhibited higher absolute levels of infestation after two years (Figure 2). Cowpea is a species with a significant volume of dry matter; however, it rapidly degrades in the soil, due to its low $\mathrm{C}: \mathrm{N}$ ratio (Azevedo \& Spehar, 2002); this exposes the soil surface to sunlight and other environmental factors faster in areas previously grown with cowpea than areas grown with plant species whose residues present higher $\mathrm{C}: \mathrm{N}$ ratios in the biomass.

In terms of weed species present, the area with cowpea in the rotation exhibited Conyza bonariensis among the species present; this species is positively photoblastic (seeds stimulated to germinate by light), indicating higher light availability to seedlings in this area compared to the rotation with no cowpea. S. grisebachii was the most important species in the rotation including cowpea (51\% of importance), while in the area with no cowpea it represented only about $15 \%$ of the overall infestation (Table 2). In the crop rotation involving corn (area 9) $R$. brasiliensis was the most important weed species, being responsible for about $54 \%$ of the overall infestation in that area.

The diversity coefficient of Simpson (D) quantifies, in simple terms, the probability of two individuals randomly collected in the same area to be from the same species. The diversity coefficient of Shannon-Weiner $\left(\mathrm{H}^{\prime}\right)$, on the other hand, derives from the Theory of the Information and sometimes confuses diversity with richness of species (Barbour et al., 1998). The diversity coefficient of Simpson showed three groups of treatments in terms of species balancing within the area: (a) those formed by areas with a single weed species $(\mathrm{D}=0)$; (b) the ones with low diversity $(0.15 \leq \mathrm{D} \leq 0.37)$; and (c) the ones with higher plant diversity $(\mathrm{D}>0.55)$ (Table 3$)$. Although this is an empirical classification, crop 
Table 3 - Diversity indexes of Simpson (D) and ShannonWeiner (H') as a function of distinct intercropping systems involving Jatropha curcas plantations. Embrapa Western Agriculture, Dourados-MS, Brazil, 2012

\begin{tabular}{|c|r|r|}
\hline & $\mathrm{D}$ & $\mathrm{H}^{\prime}$ \\
\hline Area 1 & 0.15 & 0.32 \\
\hline Area 2 & 0.15 & 0.37 \\
\hline Area 3 & 0 & 0 \\
\hline Area 4 & 0 & 0 \\
\hline Area 5 & 0.28 & 0.53 \\
\hline Area 6 & 0 & 0 \\
\hline Area 7 & 0.37 & 0.67 \\
\hline Area 8 & 0.24 & 0.49 \\
\hline Area 9 & 0.55 & 1.04 \\
\hline Area 10 & 0.62 & 1.12 \\
\hline
\end{tabular}

rotation systems allowed the formation for a more balanced flora. Shannon-Weiner showed a similar classification.

According to Correia \& Durigan (2004), diversity is not directly related to higher infestation levels. Concenço et al. (2011b) report that proper management in agricultural cropping systems allows formation of a larger and more diverse weed seed bank in the soil, increasing the number of species present and reducing the occurrence of most weed species. Areas with crop rotation in the interrows of Jatropha caused a reduction, for example, in the occurrence of the most common weed species observed in the area: S. grisebachii. While this species accounted for $82 \%, 83 \%$ and $72 \%$ of the total infestation, respectively, in the control plot (area 1), Stylosanthes (area 2) and crotalaria (area 8) treatments, in the rotations (areas 9 and 10) it accounted for only about $52 \%$ of the infestation (Table 2). This is mirrored by the lower diversity indexes in the areas with no crop rotation compared to areas where rotation was established (Table 3).

The cluster analysis showed the nesting pattern for areas, according to their levels of similarity (Figure 3). The clustering tree obtained by the UPGMA method was validated with cophenetic correlation coefficient equal to $86 \%$. The cluster analysis showed only two area groupings at the threshold level based on the mean of the original similarity matrix of

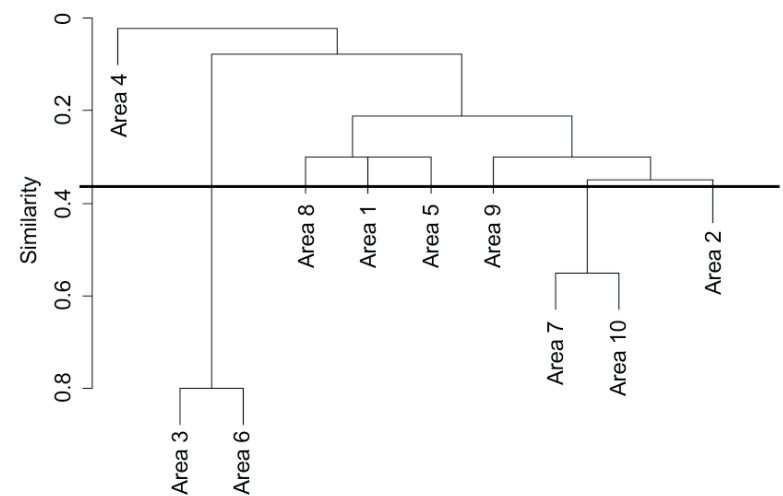

Figure 3 - Cluster analysis of distinct intercropping systems involving Jatropha curcas plantations based on their similarity of weed species. Distances were estimated by the Jaccard's similarity coefficient; grouping was established based on the UPGMA method. Embrapa Western Agriculture, Dourados-MS, Brazil, 2012.

Jaccard: (1) areas 3 and 6, and (2) areas 7 and 10 (Figure 3). The first grouping compared the species of grasses Brachiaria and Panicum, and the grouping was formed because the sole weed species found in both areas was S. grisebachii (Table 2), while the second grouping was formed because all species present in area 7 were also observed in area 10 , also with relatively similar occurrence levels (Table 2). It is worth noting that both crop rotations (areas 9 and 10) were not grouped together; the primary reason was the occurrence of $C$. bonariensis only in area 9 , and C. benghalensis only in area 10; both of them are important weed species because the former presents biotypes with resistance to the herbicide glyphosate, and the latter is highly tolerant to the same herbicide.

In summary, areas with low soil coverage resulted in higher infestation levels when crops or forages are intercropped with Jatropha; crop rotation in the interrows of Jatropha caused a significant reduction in weed infestation, but the lowest infestation levels were observed when grasses, mainly from the Genus Brachiaria, were grown in the interrows of the Jatropha crop. Although the majority of the overall infestation was attributed to S. grisebachii, weed species differed according to the plant species and/or crop rotation scheme tested; Conyza bonariensis, an important weed species due to its resistance to the herbicide glyphosate, was observed in 
areas with deficient mulching at least part of the year. Lower diversity coefficients were associated with more severe occurrence of the most troublesome weed species. In the first years after planting Jatropha, species of Brachiaria or a crop rotation involving species with high mulching ability and whose biomass present high $\mathrm{C}: \mathrm{N}$ ratio, should be established in the interrows to avoid problems with weeds infestation.

\section{ACKNOWLEDGMENTS}

Os autores agradecem a FINEP (Convênio no 01.10 .0015 .00 ) e a FUNDECT (Termo Outorga no 0067/09), pelo apoio financeiro a esta pesquisa.

\section{LITERATURE CITED}

AUN, K. H. Agribusiness of Jatropha curcas: from vision to reality. In: INTERNATIONAL PLANTATION INDUSTRY CONFERENCE AND EXHIBITION, 2., 2008, Shah Alam. Proceedings... Selangor: International Institute of Plantation Management, 2008. CD ROM.

AZEVEDO, D. M. P.; SPEHAR, C. R. Decomposição da palhada de culturas para plantio no período de safrinha em solos de tabuleiros costeiros. Teresina: Embrapa Meio Norte, 2002. 4 p. (Embrapa Meio Norte. Comunicado Técnico, 147).

BARBOUR, M. G. et al. Terrestrial plant ecology. Menlo Park: Benjamin/Cummings, 1998. 688 p.

BROLMANN, J. B. Cold tolerance of Stylosanthes species. Trop. Grasslands, v. 13, n. 2, p. 87-91, 1979.

CARVALHO, L. B.; BIANCO, M. S.; BIANCO, S. Estimativa da área foliar de Synedrellopsis grisebachii usando método não destrutivo. Planta Daninha, v. 29, p. 1023-1027, 2011. (Número Especial)

CONCENÇO, G.; SALTON, J. C.; CECCON, G. Dinâmica de plantas infestantes em sistemas integrados de cultivo. Dourados: Embrapa Agropecuária Oeste, 2011a. 51 p. (Embrapa Agropecuária Oeste. Documentos 114).

CONCENÇO, G. et al. Effect of long-term agricultural management systems on occurrence and composition of weed species. Planta Daninha, v. 29, n. 3, p. 515-522, 2011 b.

CORREIA, N. M.; DURIGAN, J. C. Emergência de plantas daninhas em solo coberto com palha de cana-de-açúcar. Planta Daninha, v. 22, n. 1, p. 11-17, 2004.
GOMES, G. L. G. C. et al. Cadastramento fitossociológico de plantas daninhas na bananicultura. Planta Daninha, v. 28, n. 1, p. 61-68, 2010.

OLIVEIRA, H. N.; SILVA, C. J. Artrópodes benéficos na cultura do pinhão-manso em Mato Grosso do Sul. Dourados: Embrapa Agropecuária Oeste, 2011. (Embrapa Agropecuária Oeste, Comunicado Técnico, 164).

R DEVELOPMENT CORE TEAM. R: A language and environment for statistical computing. Vienna: R Foundation for Statistical Computing, 2012. Available at: $<$ http://www.Rproject.org/>. Accessed in: 2 jan. 2012.

ROCHA, P. R. R. et al. Seletividade de herbicidas préemergentes ao pinhão-manso (Jatropha curcas).

Planta Daninha, v. 28, n. 4, p. 801-806, 2010.

SILVA, A. A. et al. Biologia de plantas daninhas. In: SILVA, A. A.; SILVA, J. F. (Ed.). Tópicos em manejo de plantas daninhas. Viçosa, MG: Universidade Federal de Viçosa, 2007. p. 17-61.

SILVA, J. A. N. et al. Crescimento e produção de espécies forrageiras consorciadas com pinhão-manso. Pesq. Agropec. Bras., v. 47, n. 6, p. 769-775, 2012.

SNEATH, P. H.; SOKAL, R. R. Numerical taxonomy: the principles and practice of numerical classification. San Francisco: W. H. Freeman, 1973. 573 p.

SOKAL, R. R.; ROHLF, F. J. The comparison of dendrograms by objective methods. Taxon, v. 11, n. 1, p. 33-40, 1962.

STAUT, L. A.; SILVA, C. J.; CONCENÇO, G. Período crítico de competição com plantas daninhas na cultura do pinhãomanso. In: CONGRESSO BRASILEIRO DE PESQUISA EM PINHÃO-MANSO, 2., 2011, Brasília, DF. Anais... Brasília, DF: Embrapa Agroenergia/ABPPM, 2011. CD ROM.

VARGAS, L.; ROMAN, E. S. Manual de manejo e controle de plantas daninhas. Bento Gonçalves: Embrapa Uva e Vinho, 2004. 652 p.

VELYKIS, A.; SATKUS, A. Influence of crop rotations and reduced tillage on weed population dynamics under Lithuania's heavy soil conditions. Agron. Res., v. 4, n. 2, p. 441-445, 2006.

VOLL, E. et al. A dinâmina das plantas daninhas e práticas de manejo. Londrina: Embrapa Soja, 2005. 85 p. (Embrapa Soja. Documentos, 260). 